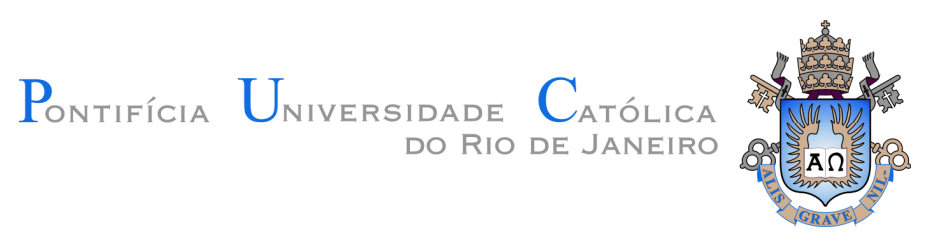

Marta Baltar Moreira Areosa

Informational Frictions and Inflation Dynamics

Thesis presented to the Postgraduate Program in Economics of the Departamento de Economia, PUC-Rio as partial fulfillment of the requirements for the degree of Doutor em Economia

Advisor: Prof. Vinicius do Nascimento Carrasco

Rio de Janeiro

April 2010 


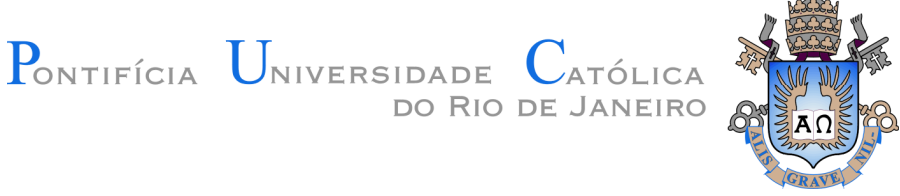

Marta Baltar Moreira Areosa

\section{Informational Frictions and Inflation Dynamics}

Thesis presented to the Postgraduate Program in Economics of the Departamento de Economia, PUCRio as partial fulfillment of the requirements for the degree of Doutor em Economia.

Approved by the following commission:

Prof. Vinicius do Nascimento Carrasco

Advisor

Departamento de Economia - PUC-Rio

Prof. Leonardo Bandeira Rezende

Departamento de Economia - PUC-Rio

Prof. Luciano Vereda Oliveira

Instituto de Gestão de Riscos Financeiros e Autoriais - PUC-Rio

Fabio Araújo

Banco Central do Brasil

Márcia Saraiva Leon

Banco Central do Brasil

Prof. Mônica Herz

Coordinator of the Centro de Ciências Sociais - PUC-Rio

Rio de Janeiro-April 20, 2010 
All rights reserved.

\section{Marta Baltar Moreira Areosa}

Marta Baltar Moreira Areosa graduated from the Universidade Federal do Rio de Janeiro (Rio de Janeiro, Brasil) in Electronic Engineering in 1995 and obtained a Master degree in Mathematical Economics at Instituto Nacional de Matemática Pura e Aplicada in 2004.

Bibliographic Data

Areosa, Marta B. M.

Informational Frictions and Inflation Dynamics / Marta Baltar Moreira Areosa ; advisor: Vinicius do Nascimento Carrasco. - 2010. $106 \mathrm{f} .:$ II ; $30 \mathrm{~cm}$

Tese (Doutorado em Economia)-Pontifícia Universidade Católica do Rio de Janeiro, Rio de Janeiro, 2010. Inclui bibliografia

1. Economia - Teses. 2. Fixação de Preços. 3. Informação Dispersa. 4. Complementaridades. 5. Crenças de Ordem Superior. 6. Rigidez de Informação. 7. Curva de Phillips. I. Carrasco, Vinicius do Nascimento. II Pontifícia Universidade Católica do Rio de Janeiro. Departamento de Economia. III. Título

CDD: 330 


\section{Acknowledgements}

I'm indebted to all professors of the Economic Department, especially to my advisor, Vinicius Carrasco, for many invaluable comments.

I would also like to thank Banco Central do Brasil for the financial support. The views expressed in this thesis are those of the author and do not necessarily reflect those of the Banco Central do Brasil.

I am also grateful to my classmates, for their complicity, to my family and friends, for their encouragement and for being so understanding with my detachment, and in particular to my husband, for everything. 


\section{Abstract}

Marta Baltar Moreira Areosa. Informational Frictions and Inflation Dynamics. Rio de Janeiro, 2010. 106p. Tese de Doutorado Departamento de Economia, Pontifícia Universidade Católica do Rio de Janeiro.

This thesis encompasses three essays on price setting under stickydispersed information (SDI). The baseline framework mixes the sticky information model of Mankiw and Reis (2002) with dispersed information models like Morris and Shin (2002) and Angeletos and Pavan (2007). In Chapter 1, we derive the equilibrium of the game assuming that firms face strategic complementarity on their pricing decisions. In this context, firms take their pricing decisions using information to build expectations on the prices set by other firms and on the current state of aggregate nominal demand - the fundamental of the economy. In Chapter 2, we extend the SDI model to analyze how central bank communication affects price setting. As public information help firms to infer the current state of the economy and one another's prices, it improves price synchronization. This effect makes inflation variance increase with the precision of the public information. Social welfare is affected by the fact that firms do not internalize how their prices change other firms' pricing decisions. In Chapter 3, we use a SDI model to analyze how price setting changes when the interest rate is a policy instrument that not only partially drives the fundamental dynamics, but also it is understood as a public signal that informs the view of the monetary authority on the current state of the economy. Under this framework, firms use interest rate to support their pricing decisions, influencing inflation dynamics. We also obtain the optimal parameters of the policy instrument (regarding three different efficiency criteria), considering that the central bank knows that firms take information from its actions.

\section{Keywords}

Price Setting, Dispersed Information, Complementarities, Higher-Order Beliefs, Sticky Information, Phillips Curve. 


\section{Resumo}

Marta Baltar Moreira Areosa. Fricçoes Informacionais e Dinâmica da Inflação. Rio de Janeiro, 2010. 106p. Tese de Doutorado - Departamento de Economia, Pontifícia Universidade Católica do Rio de Janeiro.

Esta tese incorpora três ensaios acerca de fixação de preços com informação rígida e dispersa (IRD). A estrutura básica mistura o modelo de rigidez de informação proposto em Mankiw and Reis (2002) com o modelo de informação dispersa descrito em Morris and Shin (2002). No capítulo 1, obtémse o equilíbrio do jogo assumindo que as firmas se deparam com complementaridade estratégica em suas decisões de preço. Neste contexto, as firmas tomam suas decisões de preço utilizando a informação disponível para prever os preços das outras firmas e a demanda agregada nominal, o fundamento da nossa economia. Estuda-se a importância de cada parâmetro do modelo em vários contextos. No capítulo 2, estende-se o modelo IRD para analisar como a comunicação do banco central interfere na fixação de preços. Como informação pública ajuda às firmas a prever o estado atual da economia e as ações uma das outras, ela ajuda na sincronia dos preços. Este efeito faz a variância da inflação aumentar com a precisão da informação pública. Além disso, o bem-estar da sociedade é afetado pelo fato de que as firmas tomam suas decisões de preços sem considerar como isto influenciará a decisão das outras firmas. No capítulo 3, utilize-se o modelo com IRD para analisar como a fixação de preços muda quando a taxa de juros, além de ser um instrumento de política capaz de influenciar a dinâmica do fundamento, também é vista como um sinal público que informa a visão da autoridade monetária acerca do estado atual da economia. Sob este arcabouço, firmas utilizam a taxa de juros para embasar suas decisões de preços. Obtêm-se também os parâmetros ótimos do instrumento de política (para três medidas diferentes de bem-estar), considerando-se que o banco central sabe que as firmas extraem informação de suas ações.

\section{Palavras-chave}

Fixação de Preços, Informação Dispersa, Complementaridades, Crenças de Ordem Superior, Rigidez de Informação, Curva de Phillips. 


\section{Contents}

1 A Sticky-Dispersed Information Phillips Curve: A Model with Partial and Delayed Information

1.1. Introduction

1.2. The Model

1.3. Equilibrium

1.4. Benchmarks for the SDI Phillips Curve

1.5. Inflation Behavior under SDI

1.6. Conclusion

2 Central Bank Communication and Price Setting

2.1. Introduction

2.2. The Model

2.3. Equilibrium

2.4. Inflation 39

2.5. Policies

43

2.6. Conclusions

46

3 Optimal Informational Interest Rate Rule

48

3.1. Introduction

48

3.2. The Model

50

3.3. Equilibrium

3.4. Informational Effect 55

3.5. Inflation Dynamics 57

3.6. Efficiency Criteria 62

3.7. Conclusions

69

4 Bibliography 